\title{
Influence of School Farm on Teaching of Agricultural Science in Senior Secondary Schools in Ikwuano Local Government Area, Abia State
}

\author{
Michael Onwumere1, Melody N. Modebelu², Isiwu Edward Chukwuka1 \\ ${ }^{1}$ Department of Agricultural and Home Economics Education, College of Agricultural and Science Education, \\ Michael Okpara University of Agriculture, Umudike, Nigeria \\ ${ }^{2}$ Department of Educational Management, College of Agricultural and Science Education, Michael Okpara \\ University of Agriculture, Umudike, Nigeria \\ Email: onwumeremichael@gmail.com,meloodyne@gmail.com, edisiwu50@yahoo.com
}

Received 16 May 2016; accepted 24 June 2016; published 27 June 2016

Copyright (C) 2016 by authors and OALib.

This work is licensed under the Creative Commons Attribution International License (CC BY).

http://creativecommons.org/licenses/by/4.0/

(c) (i) Open Access

\section{Abstract}

This work examined the influence of school farm on the teaching of Agricultural Science in senior secondary schools in Ikwuano Local Government Area of Abia State. The study utilized a descriptive survey research design with random sampling techniques. The twelve public senior secondary schools in Ikwuano Local Government Area of Abia State were purposively selected and used for the study. There was no sampling carried out for the study because of the small population rather all the 12 agricultural science teachers drawn from the 12 schools were used (one agricultural science teacher from each of the twelve schools selected). Two research questions and one null hypothesis guided the study. Instruments for data collection were a 10-item structured questionnaire built on a 4-point response format. The validity of the instrument was determined by three experts: one in agricultural education, one in educational administration and one in measurement and evaluation. Cronbach alpha was used to determine the internal consistency reliability index value of the items to be 0.86 . Mean, pool mean and standard deviation were used in answering the two research questions. t-test statistic tool was used to test the null hypothesis at 0.005 . The findings of the study reveal that school farm has a positive influence on the teaching of agricultural science in senior secondary schools in Ikwuano Local Government Area of Abia State. Based on these findings, it was recommended among others that government and even the school management should always ensure the establishment of a functional school farm in schools and both the agricultural science teachers and the students on their own should always ensure proper management and utilization of the school farm. 


\title{
Keywords
}

\author{
Influence, School Farm, Teaching of Agriculture, Agricultural Science, Senior Secondary Schools, \\ and Ikwuano L.G.A.
}

\author{
Subject Areas: Education
}

\section{Introduction}

Agriculture plays an important role in the development of many developing nations; hence there is a need to focus on sustainability and increased agricultural productivity [1]. It remains the basic source of livelihood for more than half of the world's population. In some countries, more than four-fifths of the inhabitants support themselves by farming while in the more industrialized countries the proportion ranges much lower to less than 3 percent in both the United States of America and Great [2]. More so, the branches of agriculture are as follows: agronomy, horticulture, agricultural engineering, animal science and agricultural economics [3]. Agriculture is the oldest industry known to mankind. It is the basic source of food and raw materials for many industries [4]. It can be justifiably referred to as the world' primary industry.

In Nigeria, agriculture is a major sector of the economy, providing employment for about $70 \%$ of the population. The sector is being transformed by commercialization at the small, medium and large scale enterprise level [5]. In 1990, 82 million hectares out of Nigerian's total land area of about 91 million hectares were found to be arable. 42 percent of the cultivable area was farmed; much of this land was farmed under the bush fallow system whereby lands are left idle for a period of time to allow natural regeneration of soil fertility. 18 million hectares were classified as permanent pasture, but had the potential to support crops [5]. It contributed about $32 \%$ to GDP in 2001 and the country's agricultural products fall into two main groups vizfood crops produced for home consumption and exports [5].

The youth which is the life-wire of every society are encouraged into farming through Young Farmers Club (YFC) and sometimes have their farms or gardens. They receive information and in some cases assist them in analyzing innovations towards agricultural development. It is however unfortunate that in spite of the little efforts or contributions by the youths-household agriculture, empirical data are lacking on their participation maybe because of inadequate exposure to practical agriculture during their secondary school days or lack of practical skills. Thus, the scope of their involvement has not been statistically ascertained. The attendant knowledge gap has not permitted the formulation of articulate policies for the improvement. Several youth programmers on agriculture have operated and failed due to unreliable data, information and inadequate skills on what determines the youth's participation in rural agriculture for the design of appropriate intervention strategies [6]. Based on the aforementioned reasons, Nigerian government made agricultural science as a subject compulsory in all secondary schools (both in junior and senior), so as to develop and improve effective learning of agricultural science [7]. The 9-3-4 system of education was further introduced for this purpose [7]. More so, this will help the students to acquire knowledge and practical skills in agriculture and to prepare students for agricultural occupations [1].

The main task of the teachers is to facilitate teaching and learning using various means and media. For a success to be recorded in this therefore, the teacher must know and understand the meaning and the process of learning. According to [8], teaching is the art or process of imparting knowledge and skills. It involves all the activities of educating or instructing an individual on the right ways of life. More so, a teacher is someone who delivers an educational program, and assesses students' performance in a school setting. Teaching maybe carried out informally within the family which is called homeschooling or in the wider community. Formal teaching may be carried out by paid professionals and such professionals enjoy a status in some societies on a par with physicians, lawyers, engineers and accountants etc. A teacher's professional duties may extend beyond formal teaching. Outside of the classroom, teachers may accompany students on the field trips, supervise study halls, help with the organization of the school functions and serve as a supervise for extracurricular activities [9]. Essentially, the general principles of teaching are that teachers with adequate readiness teach more effectively, efficiently and better-a motivated teacher teaches better than the unmotivated one. 
School farm is also a component of the school activities which has link with the birth of a more productive agriculture. It is a selected plot of land in the school environment where students' carryout practical agriculture both in crop production and animal husbandry [1]. This he said helps the students to acquire knowledge and practical skills in agriculture and agricultural related opportunities. [10] outlined some of the benefits of school farm to students to include:

1) Generating circumstances for students to market agricultural products.

2) Providing students with supervised occupational experience in agricultural productivity.

3) Encouraging the use of records and reports similar to those used in agriculture.

Also, [11] stated that school principals rated the school farm as very important in giving students practical experience, promoting agricultural skills by giving the students opportunities to carryout demonstration plots and conduct agricultural experiments among others. Generally, agricultural science is a subject in secondary school that is being taught by both male and female teachers. [11] stated that most school farms are faced with lack of tools, equipment and other capital items. Lack of seeds, feeds, fertilizer and other operating suppliers, inadequate training for teachers to use the farm for instructional purposes. In addition, lack of staff personnel to run the farm was seen as the most serious problem facing the school farm. Closely followed by lack of updated equipment and machinery are inadequate state of the art facilities. This came next as a problem rated as the highest serious problem by almost $60 \%$ of the principals (interviewed). Other problems include lack of agricultural inputs, lack of production of agricultural goods for internal consumption [12].

[13] stated that problems associated with school farm are; lack of adequate teachers, lack of laboratory facilities, lack of equipment, small amount of land and attitudinal problem of students, the host community and the unserious attitude on the part of the administrators. Poor funding of the vocational agriculture in secondary schools, keeping abreast with development in the field of vocational agriculture and communication of such development to students and the administration of vocational agriculture by non-specialists are problems facing the school farms [14]. More so, inability of the curriculum to transmit employable skills to students, lack of required materials and resources for vocational agriculture delivery and lack of interest on the part of students pose as a problem to school farm [14].

\subsection{Statement of the Problem}

It is secret to no one that economies of the world are not in good shape [15]. All economic indices today point to a decline across the globe. Thus, countries such as America, United Kingdom among others who used to have a stable economy are today battling with unemployment, declining value of the currency and even mass retrenchment of a section of the workforce especially occupations relating to agriculture [15]. In Nigeria, the situation is even gloomier; unemployment is increasing at alarming rates. Hordes of unemployed graduates roam the streets in search of the non-existing white collar jobs. Nigeria universities roll out thousands of fresh graduates every year without any prospect of them getting employed and most of these graduates are not employable because they lack the practical knowledge and skills require of the workforce [15]. More so, the problem of this lack of required practical skills among Nigerian youths even after graduation to a greater extent is probably due to unfavorable disposition or exposure of the young ones to agricultural/farm practical especially during their secondary school days [12]. Therefore, this calls for the need to determine the influence of school farm on the teaching of agricultural science especially in senior secondary schools in Ikwuano Local Government Area of Abia State.

The main purpose of this research was to determine the influence of school farm on the teaching of Agricultural Science in senior secondary school in Ikwuano Local Government Area of Abia State of Nigeria. Specifically, the study sought to:

1) Determine the level of influence of teachers' attitude to school farm on the teaching of Agricultural Science in senior secondary school in Ikwuano Local Government Area of Abia State of Nigeria.

2) Determine the extent school farm influences the effective teaching of agricultural science in senior secondary schools in Ikwuano Local Government Area of Abia State, Nigeria.

\subsection{Research Questions}

Two research questions guided the study.

1) What is the level of influence of teachers' attitude towards school farm on the teaching of agricultural 
science in senior secondary school in Ikwuano Local Government Area of Abia State of Nigeria?

2) To what extentdoes school farm influences effective teaching of agricultural science in senior secondary school in Ikwuano Local Government Area of Abia State of Nigeria?

\subsection{Null Hypothesis}

H01: There is no significant differences between the mean responses of male and female teachers on the influence of school farm on the teaching of agricultural science in senior secondary school in Ikwuano Local Government Area of Abia State of Nigeria.

\section{Methodology}

A descriptive survey research design was adopted for this study. Descriptive survey deign is the one in which information is collected without changing the environment (i.e. nothing is manipulated). The area of study wasconducted in Ikwuano local Government Area of Abia State, Nigeria [16]. The population of the study consisted of all the twelve agricultural science in Umuahia educational zone, AbiaState [17].

The selected schools for the study are all co-education system and the Agricultural science teachers in these schools are of both the male and female gender. Moreso, all the teachers selected for the study are experienced in the teaching of the agricultural science subject.

There was no sampling carried out for the study because of the small nature of the population, rather all the 12 agricultural science teachers drawn from the 12 schools were used. Ten-item researcher's made questionnaire was used as instrument for data collection for the study. The instrument was prepared and tagged "Agricultural science teacher's response questionnaire (ASTRQ)". ASTRQ elicit information from agricultural science teachers on the influence of school farm on teaching. The items were based on the research questions derived.

The instruments were validated for face and content validity by three experts in Agriculture Science, Education Administration and Measurement and Evaluation. Modifications were made based on the corrections and suggestions which were reflected in the final draft used. The reliability of the instruments was established. The instrument was trial tested twice in an interval of two weeks to 5 agricultural science teachers from the six schools outside the study area. Data gathered from their responses were analyzed using Pearson Product Moment Correlation coefficient and a reliability coefficient of 0.86 was obtained. This coefficient made the instrument highly reliable to be used for the study.

The researcher personally administered the 12 copies of the questionnaire to the 12 respondents in the twelve senior secondary schools in Ikwuano Local Government Area of Abia State. After the administration, the entire copies of the questionnaire were retrieved same day for data analysis.

In analyzing the data collected, mean, standard deviation and pooled mean were used to answer the two research questions. The Four Point Rating Scale response format of Very High Level (VHL) = 4, High Level (HL) $=3$, Low Extent $($ LE $)=2$, Very Low Level $($ VLL $)=1$ and Very High Extent $($ VHE $)=4$, High Extent $($ HE $)=3$, Very Low Extent (VLE) $=2$ and low Extent (LE) $=1$ for research question $1 \& 2$ respectively. The cut-off score is 2.50 items equal and above the score were accepted as high extent while items below 2.5 are seen as low extent.

t-test was used to test the hypotheses at 0.05 level of significance. The null hypothesis is accepted if the calculated value is less than the Critical Table value vice-versa. Any mean of 2.50 and above signifies Agreed or High extent while mean value below it indicates Disagreed or low extent.

\section{Results}

The results of the study are presented as shown in the tables below.

Results in Table 1 shows that the mean responses of Agricultural Science teachers in items 1, 3 and 4 were above the mean bench mark of 2.50 while their mean ratings in items 2 and 4 respectively were below the mean benchmark of 2.50. The pooled mean of 2.94 which was equally above the mean benchmark affirms that Agricultural Science teachers have high attitudes towards school farms.

Table 2 shows that the pooled mean rating of teachers in all the items were above the mean benchmark of 2.50. These however indicates high extent. The pooled mean of 2.83 which is also above the mean benchmark shows that teachers were in agreement that school farm influence the teaching of Agricultural Science to a high extent. 
Table 1. Mean ratings of agricultural science teachers on the level of influence of teachers' attitude to school farms for improved teaching of Agricultural Science in the study area?

\begin{tabular}{|c|c|c|c|c|}
\hline $\mathrm{S} / \mathrm{N}$ & Parameters & Mean & SD & Decision \\
\hline 1 & Teachers make use of the school farm while teaching agricultural Science & 3.67 & 0.29 & High level attitude \\
\hline 2 & Teachers are reluctant to use the school farm while teaching agricultural science & 2.38 & 0.51 & Low level attitude \\
\hline 3 & Teachers encourage the students to always visit the school farm & 3.00 & 0.60 & High level attitude \\
\hline 4 & Teachers do not make use of the school farm while teaching & 1.85 & 0.62 & Low attitude \\
\hline 5 & Teachers always emphasize the adequate use of school farm & 3.82 & 0.67 & High attitude \\
\hline
\end{tabular}

Pooled mean (X) 2.94 high level attitude.

Table 2. Analysis of mean ratings of agricultural science teachers on the extent influence of school farm on the effective teaching of agricultural science in the study area.

\begin{tabular}{|c|c|c|c|c|}
\hline $\mathrm{S} / \mathrm{N}$ & Parameters & Mean & SD & Decision \\
\hline 6 & School farm makes teaching of agriculture easy & 3.42 & 0.51 & High extent \\
\hline 7 & Students understands better when I teach using the school farm & 3.25 & 0.45 & High extent \\
\hline 8 & Teaching agricultural science in the school farm enhances effective teaching & 3.42 & 0.67 & High extent \\
\hline 9 & $\begin{array}{c}\text { Teachers who uses the school farm while teaching agricultural science } \\
\text { achieve instructional objectives more easier }\end{array}$ & 3.25 & 0.45 & High extent \\
\hline 10 & The use of school farm saves teaching time & 2.83 & 0.72 & High extent \\
\hline
\end{tabular}

Pooled mean (X) 2.83 high extent.

Ho1: There is no significant difference between the mean ratings of male and female teachers on the influence of school farm on the effective teaching of Agricultural Science.

t-test analysis of the mean ratings of male and female teachers on the influence of school farm on the teaching of Agricultural Science in Ikwuano LGA.

\begin{tabular}{ccccccccc}
\hline Gender & $\mathrm{N}$ & $\mathrm{X}$ & $\mathrm{SD}$ & $\mathrm{Df}$ & $\mathrm{Sd}$ & $\mathrm{t}$-cal & $\mathrm{t}$-crt & Decision \\
\hline Male & 8 & 3.46 & 0.51 & 10 & 0.39 & 0.97 & 1.96 & Accept Ho2 \\
Female & 4 & 3.08 & 0.60 & & & & & \\
\hline
\end{tabular}

This shows that the t-calculated value was 0.97 while the t-critical value was 1.96 . Since the t-calculated value was less than the t-critical value at 0.05 level of significance, the null hypothesis was accepted. Therefore, there is no significant difference between the mean ratings of male and female teachers on the extent of school farm influence on the teaching of Agricultural science.

\section{Discussion of Findings}

In Table 1, the researcher came out with a pooled mean of 2.94. This is positive and signified that teachers attitudes towards school farm was high. Similarly, [18] also reported that teachers' attitude towards school farm is generally positive. More so, [19] lent support to the above result where he said the agricultural science teachers always show a favorable attitude towards their teaching job and use of the school farm.

The result in Table 2 indicated a pooled mean of 2.83 which implies that the school farm has a positive influence on the teaching of agricultural science. In other words, The school farm has a way of helping the agricultural science teachers achieve their teaching job more effectively and efficiently in senior secondary schools in Ikwuano Local Government Area of Abia State. This outcome is in line with the view of [11]. who perceived school as being able to help the teachers' carryout their demonstration plots and conduct agricultural experiments. 


\section{Conclusion}

From the work, it is discernable that the school farm is capable of contributing positively to the teaching of agricultural science in senior secondary schools in Ikwuano Local Government Area of Abia State. The agricultural science teachers need to continue to show a more favorable attitude towards their teaching job and the use of the school farm in order to arouse that of the students. In addition, functional school farm is needed by schools from all stakeholders (federal, state, local government and even school management) as this will help to allow for more effective and efficient teaching of agricultural science subjects. More so, the main limitation of this study is time constraint and inadequate finance.

\section{Recommendations}

Based on the findings, the following recommendations were outlined:

1) The government and even the school management should always ensure the establishment of a functional school farms in schools.

2) Agricultural science teachers and the students should always ensure proper management and utilization of the school farm.

3) The equipment used for effective utilization of the school farm should always be provided for the teachers and students to make use of the school farm.

\section{References}

[1] Akinsorotan, O.A. (2007) Effect of School Agricultural Programme of Oyo State on Career Choice of School Students in Ibadan South West Local Government Area of Oyo State, Nigeria. Agricultural Journal, 2, 667-671.

[2] Adato, M. and Meinzen-Dick, R. (2007) Agricultural Research, Livelihoods, and Poverty: Studies of Economic and Social Impacts in Six Countries. Johns Hopkins University Press Food Policy Report.

[3] Rimando, T.J. (2004) Crop Science: Fundamentals of Crop Science, U.P. Hosbernes, University Publication Office.

[4] Ukpe, O.U. (2008) Effect of Micro-Credit on the Average of Small Scale Farmers in Akwa Ibom State, Nigeria. An Unpublished M.Sc. Thesis, Michael Okpara university of Agriculture, Umudike.

[5] Ade, O.S. (2007) Strategies for Managing the Opportunities and Challenges of the Current Agricultural Commodity, Booms in SSA. Seminar Paper on Managing Community in Sub-Saharan Africa. Publication of AERC Senior Policy Seminar IX, Africa Economic Research Consortium (AERC), Nairobi.

[6] Agidi, G.A. (2014) Issues, Paper Educational Content and Delivery System Related to Moral Youth Programmes. Ministry of Agriculture, Livestock Department and Marketing, Kenya.

[7] (2013) Federal Republic of Nigeria-FRN.

[8] Crowther, K.J.K. and Assby, M. (2008) Oxford Advanced Learner’s Dictionary. Current Edition, Oxford University Press.

[9] Wright, I.V. (2011) Bucknell.edu.

[10] Williams, D.J. and McCarthy, D.A. (1985) Student Benefit from School Farm Activities as Perceived by Administrators and Instructors. Journal of the American Association of Teachers Educators in Agriculture, 26, 16-23.

[11] Kochnen, T. (1994) Portuguese Secondary Agricultural Science in Transition. Journal of Agricultural Education and Extension. www.b:bwau.n/ejae(v)n-2htm

[12] Francisco, C.T.L. and Radhakrisha, R.B. (2003) The Role of the School Farm as Perceived by Brarihan, Agricultural School Principals. Proceedings of 199th Annual conference Raleigh North Carolina, USA.

[13] Fuatai, L. (2000) Factors Associated with Teaching Effectiveness as Perceived by Western Samoa Agriculture Teacher, Ministry of Education, Western Samoa.

[14] Ikeoji, C.N., Agwubike, C.C. and Disi, J.O. (2007) Perceptions of Head Agricultural. Electronic Journal of Science Education (South Western University), 11.

[15] Ezeimo, P. (2015) Imbibing Entrepreneurial Spirit among Young Minds in a Growing Economy.

[16] Post Office (2009) With Map of LGA. NIPOST.

[17] (2014) Secondary Educational Management Board.

[18] Hunter, S. (1977) Survey of Secondary School Perceptions (Research Report). ERIC Document Service Reproduction.

[19] Thomas, V. (1997) What Research Says about Administration Management Style. Effectiveness and Teacher Morale (Report No; ERIC-41-1569), 4-10. 


\section{Warmly welcome your paper submission to OALib Journal!}

- Publication on a daily basis

- 9 subject areas of science, technology and medicine

- Fair and rigorous peer-review system

- Fast publication process

- Article promotion in various social networking sites (LinkedIn, Facebook, Twitter, etc.)

- Widely-targeted and multidisciplinary audience to read your research

Submit Your Paper Online: Click Here to Submit

Contact Us: service@oalib.com 